\title{
Performance evaluation of combustion of palm kernel shell and coconut husk blend in a pilot-scale grate furnace
}

\author{
Kamoru Olufemi Oladosu*, Akeem Amao Mustapha**, Mondiu Olayinka Durowoju** and \\ Olusegun Ogunsanya** \\ *Department of Mechanical Engineering, Kwara State University, Malete, Nigeria \\ **Department of Mechanical Engineering, Ladoke Akintola University of Technology, Ogbomoso, Nigeria \\ *Corresponding Author: kamoru.oladosu@kwasu.edu.ng
}

Submitted: $12 / 09 / 2019$

Revised: $\quad 06 / 11 / 2020$

Accepted: $13 / 11 / 2020$

\begin{abstract}
Pollution resulting from the use of stereotypical fuels for energy generation has been a great menace to the air we breathe. Co-combustion of biomass fuels has proved effective against the deficiencies associated with the burning of individual biomass on its own. This study aimed at investigating the combustion of Palm Kernel Shell (PKS) and Coconut Husk $(\mathrm{CH})$ blend in a grate furnace. The proximate and ultimate analyses of the mix of PKS and $\mathrm{CH}$ were determined using ASTM 3174-76 method. Four combustion tests were carried out with a $2 \mathrm{~kW}$ grate furnace, where the effects of temperature distribution, flue gas emissions $\left(\mathrm{CO}_{2}, \mathrm{CO}\right.$, and $\left.\mathrm{NO}_{2}\right)$, and combustion efficiency were measured. All the experimental tests were performed using varying primary-secondary air ratio of (40:60). The temperature distribution at different positions (H1, H2, H3, H4, and H5) in the combustion unit using PKS and $\mathrm{CH}$ blend (PKS-CH) ratio of 100:00, 70:30, 60:40, and 50:50 was measured. Temperature data were recorded for 50 minutes after a stable bed temperature of $248.7^{\circ} \mathrm{C}$ was reached. The results indicated that the highest temperature immediately above the grate (H1) was $720.9^{\circ} \mathrm{C}$ for $60: 40$ fuel proportions. A more significant temperature difference of $356.4{ }^{\circ} \mathrm{C}$ between the bed temperature and $\mathrm{H} 1$ temperature was recorded for 70:30 fuel proportions. The average deviation from temperatures at $\mathrm{H} 1$ to $\mathrm{H} 5$ at 50 minutes of the experiment was approximately $122{ }^{\circ} \mathrm{C}$. For each cocombustion fuel option, combustion efficiency increases with time following the same pattern as $\mathrm{CO}_{2}$ emission. The combustion efficiency was maximum (62.11\%) at 70:30 PKS-CH ratios, which conversely showed a low CO emission of $302 \mathrm{ppm}$.
\end{abstract}

Keywords: co-combustion; coconut husk; grate furnace; palm kernel shell; temperature distribution.

\section{INTRODUCTION}

Residues obtained from processing agricultural products hold constituents whose values are much less than the total cost of processing for man's benefit (Obi et al., 2016). These agricultural wastes can be classified as biomass. The environmental problem resulting from the use of fossil fuel and its limited availability has instigated the demand for green energy (Basheer and Ali, 2019) and productive use of biomass as an alternative for generating energy. Moreover, the rise in climate change relative to the emission of $\mathrm{CO}_{2}$ and other greenhouse gases from fossil fuel consumption is now of global concern (Yin et al., 2008; Skreiberg et al., 2012). In mitigating these effects, however, the locked up energy bounded in biomass can be released by combustion or burning (Yin et al., 2008; Oladosu et al., 2019). Among 
the standard technologies for extraction of energy from biomass is grate furnace combustion, whose efficiency, based on the type of fuel and mixing quality of flue gas and combustion air, has been notable on large scale designs. Yin et al. (2008) described the significance of grate assembly in a gas-fuel mixture. However, a less significant efficiency has been recorded for small scale application (Gaegauf and Salerno, 1991; Bühler, 1992; Sjaak and Jaap, 2006). Thus, low moisture content, varying particle sizes, and low ash content are considered the qualities of biomass fuels apt for grate furnaces (Thomas et al., 2019). Nussbaumer (2003) stated, on the other hand, that biomass with moisture content up to $60 \%$ could be directly burned as well. The process of combustion in a grate furnace is divided into a number of steps basically feeding of the fuel unto the grate and starting up the fire (Kuijk, 2008). Najmi and Rosli (2006) reported inadequate air-fuel mixing and fuel distribution in their investigation of the combustion characteristics of palm kernel shells in an inclined grate furnace.

Palm Kernel Shells (PKS) are carbonaceous shell fractions left after processing and crushing of palm fruit. Thermal conversion processes may convert this high carbon content as a source of heat energy (Najmi et al., 2006; Edmund et al., 2014; Husan et al., 2002; Torres-Fuchslocher and Varas-Concha, 2015; Oladosu et al., 2019). Table 1 shows the ultimate and proximate analysis of raw residues PKS carried out by Onochie et al. (2017). In the developing countries of the world, PKS is either combusted to provide the needed energy at palm oil mills or cumulated to form composts. Ordinarily, oil mills use PKS, despite its smoke emission deficiency, as fuel in boilers to produce heat and electricity. Burning PKS separately with its high nitrogen content results in significant NO emission. Because of this fact, one of the widely used countermeasures is to ameliorate the calorific value of the PKS by co-burning with woody biomass such as sawdust (Edmund et al., 2014). In the same vein, Suheri and Kuprianove (2015) took on the position that cocombustion appears as an efficient means of improving the operational problems linked with burning PKS solely. The report in previous studies on the co-combustion of biomass showed that adverse environmental impacts accompanied by burning individual fuels with low calorific value or intolerable emissions could be managed effectively by using such fuels together. Of such fuels that can be co-fired with PKS is coconut husk. Raman et al. (2011) characterized coconut husk, and the results are presented in Table 2.

Past studies on the biomass combustion suggested that air staging and fuel staging strategies can be employed to optimize the combustion performance of biomass in a fluidized bed and grate combustors (Khodaei et al., 2017; Salzmann and Nussbaumer, 2001; Ninduangdee and Kuprianov 2014; Yin and Li 2017), but the startup and running cost of operations associated with these techniques make it difficult to be operated by small scale business. Therefore, it becomes imperative to work further to enhance the combustion process in small scale grate furnace technology. This paperwork aims to investigate the combustion of a selected fuel blend, $\mathrm{PKS}-\mathrm{CH}$, with a varying proportionate mixture of the two fuels in a pilot-scale grate furnace. The work focuses on temperature and emissions at different heights in the furnace against time. In the following sections, an explanation of the experimental setup and results are presented, after which conclusions are drawn.

Table 1. Proximate and ultimate analysis of palm kernel shell (Onochie et al., 2017).

\begin{tabular}{ccccccc}
\hline \multicolumn{7}{c}{ Proximate Analysis } \\
\hline Element & Carbon & Oxygen & Hydrogen & Nitrogen & Sulfur & Calorific value \\
Weight (\%) & 47.88 & 42.69 & 5.15 & 0.94 & 0.10 & $16.9 \mathrm{MJ} / \mathrm{kg}$ \\
& & & & & \\
Property & Moisture & Ash & Fixed Carbon & Volatile matter \\
Weight (\%) & 10.23 & 3.24 & 1.42 & 85.11 & \\
\hline
\end{tabular}


Table 2. Ultimate and analysis of oven dried coconut husk (Raman et al., 2011).

\begin{tabular}{ccccccc}
\hline \multicolumn{7}{c}{ Proximate Analysis } \\
\hline Element & Carbon & Oxygen & Hydrogen & Nitrogen & Sulfur & Calorific value \\
Weight (\%) & 47.88 & 42.69 & 5.15 & 0.94 & 0.10 & $16.9 \mathrm{MJ} / \mathrm{kg}$ \\
& & & & & \\
Uroperty & Ash & Fixed Carbon & Volatile matter & & \\
Weight (\%) & 2.6 & 6.7 & 90.7 & \\
\hline
\end{tabular}

\section{MATERIALS AND METHOD \\ PKS-CH characterization}

In this study, African PKS and $\mathrm{CH}$ originated from Ogbomoso Southwestern, Nigeria, were employed as fuels. These fuels were dried in air for 3 to 4 days to remove moisture. Excessive moisture levels would significantly decrease combustion rates and lower energy recovery (Ahmad et al., 2008). The shells were crushed and further reduced to smaller grains using granulator (SG-16 Series) and blender accordingly. The grains were subsequently sieved to $6 \mathrm{~mm}$. The proximate and ultimate analyses of the samples (PKS-CH) were determined using the ASTM 3174-76 method. The result of these analyses is represented in Table 3. PKS-CH showed a very high volatile content (72.93 wt. \%), with a small amount of fixed carbon (16.76 wt. \%). The net calorific value (LHV) of the PKS-CH quantified around 18.67 $\mathrm{MJ} / \mathrm{kg}$ was established to correspond to that of PKS additives mixture (18.80 MJ/kg) by Kareem et al. (2018). Low sulphur content in PKS-CH mix also indicates less likelihood of SOx emission, consequently eliminating the need for postcombustion reduction of the emission.

Table 3. Ultimate and proximate analysis of PKS-CH blend.

\begin{tabular}{ll}
\hline Fuel & PKS-CH blend \\
\hline Proximate Analysis (\%) & \\
Moisture & 8.64 \\
Ash & 1.34 \\
Fixed Carbon & 16.76 \\
Volatile Matter & 72.93 \\
Ultimate Analysis (\%) & \\
Carbon & 51.46 \\
Oxygen & 42.67 \\
Hydrogen & 5.12 \\
Nitrogen & 0.48 \\
Sulphur & 0.03 \\
Calorific value (MJ/Kg) & 18.67 \\
\hline
\end{tabular}




\section{Experimental setup and procedure}

The furnace was designed to have a rectangular shape with a height of $1.2 \mathrm{~m}$ supported on a four-legged stand of $0.45 \mathrm{~m}$ height. The furnace has $5 \mathrm{~mm}$ thick metal wall made of mild-steel (Basheer, 2020) lined internally with refractory brick insulations with an internal area of $0.5974 \mathrm{~m}^{2}$. A schematic representation of the furnace is shown in Figure 1 .

The combustion chamber is approximately $0.4037 \mathrm{~m}^{3}$ in volume. Apart from the furnace body, the experimental setup included a manual fuel feeder, 2HP- air compressor that forces air through the primary and secondary air pipes with gate valve regulating air intake as shown in the exploded view of PKS-CH combusting furnace in Figure 2. Also, facilities for measurement such as 12 points channel temperature recorder, gas analyzer, and airflow meters were used. To ensure quality air-fuel mixture required for good combustion, a split air supply system was employed (that is, primary and secondary airflow from below and above the grate, respectively).

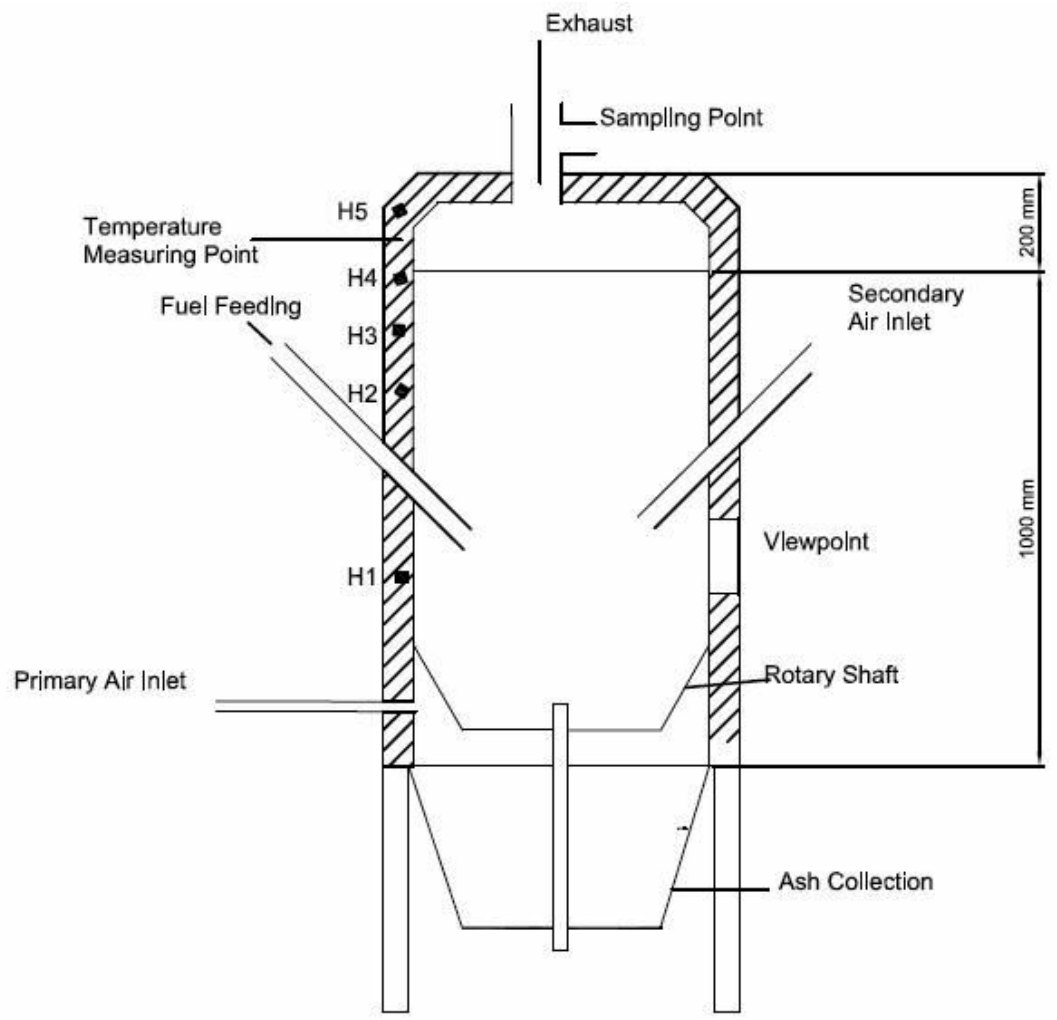

Figure 1. Schematic diagram of the combusting furnace.

All the experimental tests were performed using a staged air ratio of 40:60 (primary to secondary) of the total air supply following the optimum value also reported by Kareem et al. (2018). Combustion chamber temperatures were taken at 5 different positions above the grate using sheathed Type $\mathrm{K}$ thermocouples of $1.5 \mathrm{~mm}$ diameter and $80 \mathrm{~cm}$ long. The thermocouples were located at 100, 250, 400, 550, and $700 \mathrm{~mm}$ above the grate. These positions were labelled $\mathrm{H} 1, \mathrm{H} 2, \mathrm{H} 3, \mathrm{H} 4$, and $\mathrm{H} 5$, respectively, and the temperatures were displayed on 12 channel temperature recorder. The flue gas produced from the combustion process was evaluated using a ToxiRAE Pro gas analyzer and Aeroqual series 500 portable air quality monitor (Richard Gassman, 2015). The gas analyzer probe was positioned at the chimney to obtain the concentration of different flue gases that were produced, $\mathrm{CO}, \mathrm{CO}_{2}$, and $\mathrm{NO}_{2}$ typically. The performance of the furnace was found using a simplified formula of combustion efficiency $(\eta)$, as suggested by Nussbaumer and Good (1998). 
$\eta=100-V_{\text {therm }}-V_{\text {chem }}(\%)$

where $\mathrm{V}_{\text {therm }}$ - thermal losses of the flue gas [\%]

$\mathrm{V}_{\text {chem }}$ chemical losses of the flue gas [\%]

$\mathrm{V}_{\text {therm }}=\mathrm{f} \frac{\mathrm{T}_{\mathrm{a}}-\mathrm{T}_{\mathrm{u}}}{\mathrm{CO}_{2}}$

where $\mathrm{T}_{\mathrm{a}}$ is the temperature of the flue gas $\left[{ }^{\circ} \mathrm{C}\right], \mathrm{T}_{\mathrm{u}}$ is the ambient temperature $\left[{ }^{\circ} \mathrm{C}\right], \mathrm{CO}_{2}$ is the value read by an infrared sensor [vol.- $\%$, and $\mathrm{f}$ is the fuel-specific factor $\left[\% /{ }^{\circ} \mathrm{C}\right]$.

$\mathrm{V}_{\text {chem }}=\frac{\mathrm{CO} 11800}{\mathrm{CO}_{2}+\mathrm{CO} \frac{\mathrm{h}_{\mathrm{u} \text { atro }}}{100}-0.25 \mathrm{u}}$

where $\mathrm{h}_{\mathrm{u} \text { atro }}$ is the heating value of fuel and $\mathrm{CO}$ is carbon monoxide [vol.-\%],

and $\mathrm{CO}_{2}$ is carbon dioxide [vol.-\%]

$\mathrm{f}=\frac{20.9-\% \mathrm{O}_{2}}{\% \mathrm{CO}_{2}}$

Low and high efficiency of the combustion process are indicated by the degree of temperature in stack and gas.

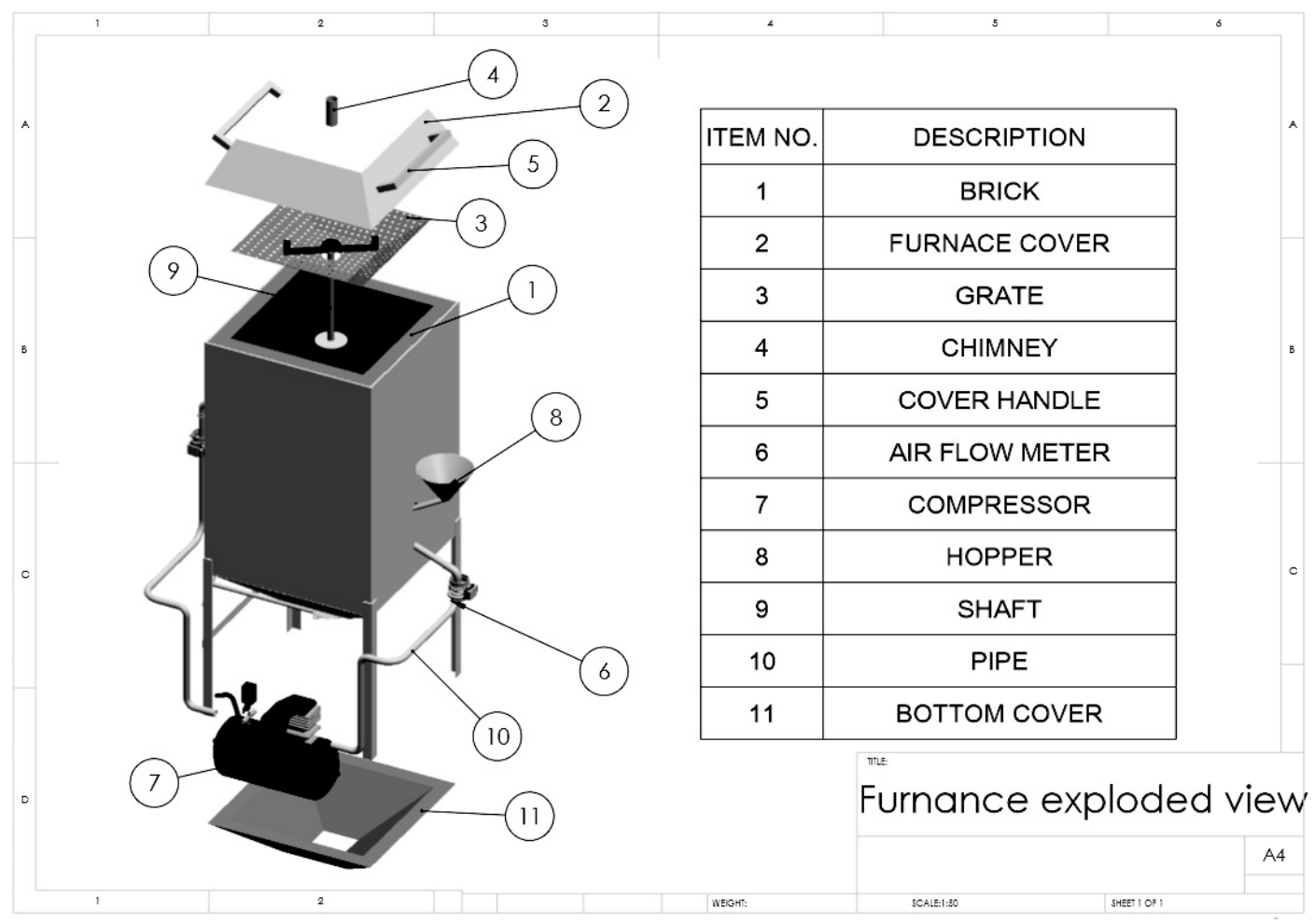

Figure 2. Exploded view of PKS-CH combusting furnace. 


\section{RESULTS AND DISCUSSION \\ Temperature distribution}

Table 4 summarizes test parameters and combustion properties at different $\mathrm{PKS}-\mathrm{CH}$ proportions and heights. Temperature data was recorded for an experiment time of about 50 minutes after a stable bed temperature of $248.7^{\circ} \mathrm{C}$ was reached. Figure 3 (a)-(d) shows the temperature profiles measured at different height H1-H5 for PKS-CH mix: (a) 100:00, (b) 70:30, (c) 60:40, and (d) 50:50. For 100:00 fuel ratio, the maximum temperature recorded was $472{ }^{\circ} \mathrm{C}$ at $\mathrm{H} 1$ immediately above the grate and $339^{\circ} \mathrm{C}$ at the exhaust port, as shown in Fig. 3(a). A higher temperature of $667{ }^{\circ} \mathrm{C}$ was recorded at $\mathrm{H} 1$ for $70: 30$ fuel mixture and $593^{\circ} \mathrm{C}$ at the exhaust port. However, the highest temperature immediately above the grate $(\mathrm{H} 1)$ was recorded to be $720{ }^{\circ} \mathrm{C}$ for $60: 40$ fuel mix. The relatively high temperature was because of the percentage of coconut husk in the fuel mixture. Even so, the highest temperature difference between the bed temperature and temperature at $\mathrm{H} 1$ was recorded to be $356{ }^{\circ} \mathrm{C}$ for $70: 30$ fuel proportion, which indicates a significant combustion temperature compared with other test cases. Coconut husk burned faster than PKS, and this helps PKS burn very well too. The low temperature above the grate for $100 \%$ PKS combustion can be attributed to the slower combustion kinetics due to slight hindrance in igniting PKS (Najmi et al., 2006), although burning of PKS during the experiment was not as difficult due to local pyrolysis of PKS done beforehand. In the tests, coconut husk catered for the deficiency of PKS in terms of preignition problem and pollution concerns.

The average difference between the temperatures at $\mathrm{H} 1$ and $\mathrm{H} 5$ at 50 minutes of the experiment was approximately $122{ }^{\circ} \mathrm{C}$. This difference shows that high gas cooling rates occurred as the combustion gases flow from the primary combustion area to the exhaust, which is only at about $83 \mathrm{~cm}$ distance vertically. The likely cause of this would be the deficient makeup of refractory bricks used for wall insulation, as well as a draught from excess combustion air towards the exit of the furnace. Appendix A (I) shows the detailed temperature distribution at different times and positions (H1, $\mathrm{H} 2, \mathrm{H} 3, \mathrm{H} 4$, and H5) in the furnace using the PKS-Coconut ratio of 100:00, 70:30, and 60:40.

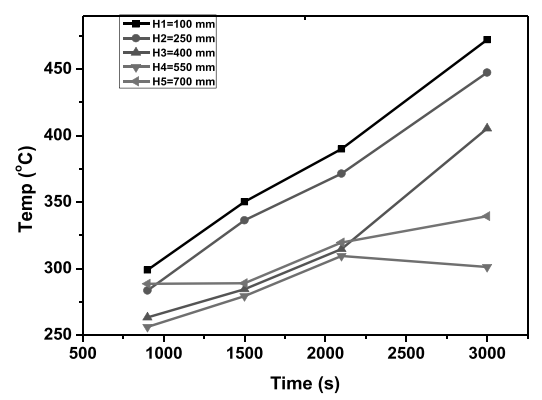

(a)

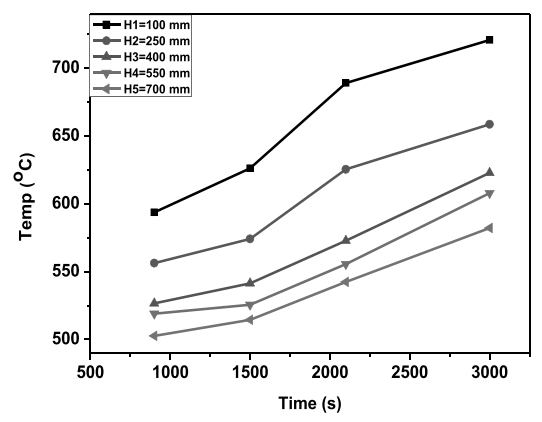

(c)

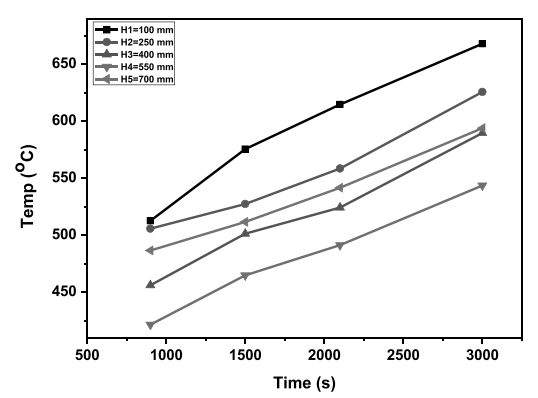

(b)

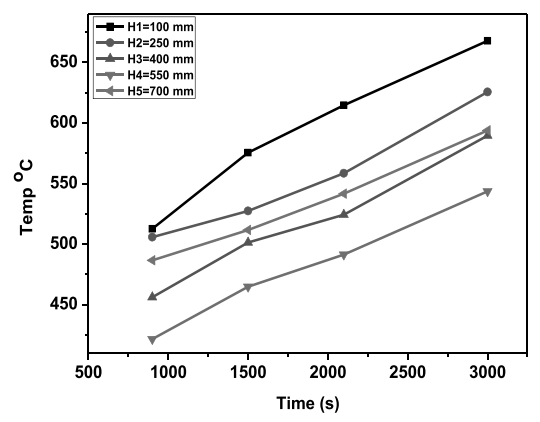

(d)

Figure 3. Temperature profile at different heights for co combustion of palm kernel shell and coconut husk proportions of (a) 100:00, (b) 70:30, (c) 60:40, and (d) 50:50. 
Table 4. Summary of temperature distribution, gaseous emission, and efficiency for PKS-CH proportions.

\begin{tabular}{|c|c|c|c|c|c|}
\hline \multirow{2}{*}{ Parameter } & & \multicolumn{4}{|c|}{ PKS-CH Fuel Proportions } \\
\hline & & 100.00 & 70.20 & 60.10 & 50.50 \\
\hline Bed Temperature ( $\left.{ }^{\circ} \mathrm{C}\right)$ & & 248 & 311 & 402 & 481 \\
\hline \multirow[t]{5}{*}{ Temperature Distribution ( ${ }^{\circ} \mathrm{C}$ ) } & H1 & $390( \pm 90)$ & $590( \pm 80)$ & $660( \pm 60)$ & $590( \pm 30)$ \\
\hline & $\mathrm{H} 2$ & $370( \pm 80)$ & $570( \pm 60)$ & $610( \pm 50)$ & $560( \pm 30)$ \\
\hline & H3 & $340( \pm 70)$ & $525( \pm 65)$ & $575( \pm 45)$ & $530( \pm 40)$ \\
\hline & $\mathrm{H} 4$ & $280( \pm 20)$ & $480( \pm 60)$ & $565( \pm 45)$ & $500( \pm 60)$ \\
\hline & H5 & $315( \pm 25)$ & $540( \pm 50)$ & $540( \pm 40)$ & $495( \pm 65)$ \\
\hline \multirow[t]{3}{*}{ Gaseous Emission (ppm) } & $\mathrm{CO}_{2}$ & 8402 & 7900 & 7783 & 7429 \\
\hline & $\mathrm{CO}$ & 321 & 302 & 352 & 319 \\
\hline & $\mathrm{NO}_{2}$ & 0.061 & 0.056 & 0.076 & 0.076 \\
\hline Carbon Combustion Efficiency (\%) & & 57.64 & 62.11 & 58.68 & 57.44 \\
\hline
\end{tabular}

\section{Effect of operating conditions on the distribution of $\mathrm{CO}_{2}, \mathrm{CO}$, and $\mathrm{NO}_{2}$}

In this experiment, baseline data was first obtained for a single combustion of $100 \%$ of palm kernel shell. Also, co-combustion tests at 70:30 and 60:30 proportions of PKS to coconut husk were performed. Figure 4 (a)-(c) shows the effect of PKS-CH blend on the emission of (a) $\mathrm{CO}$, (b) $\mathrm{CO}_{2}$, and (c) $\mathrm{NO}_{2} .100 \%$ full PKS combustion shows that the $\mathrm{CO}_{2}$ concentration in the flue gas is within the range of 8402-7052 ppm, while 70:30 proportion gave $\mathrm{CO}_{2}$ concentration range within 7475-7783 ppm, 7783- $6462 \mathrm{ppm}$ range for 60:30 proportion, and 7429-6167 ppm range for 50:50 proportion in 50 minutes of combustion. It was observed that $\mathrm{CO}_{2}$ concentration in the flue gas increases with time in the 4 experiments. It was also evident that $\mathrm{CO}$ emission was detected for the entire combustion process. The maximum level of $\mathrm{CO}$ is at $449 \mathrm{ppm}$, and the minimum is at $302 \mathrm{ppm}$ for 100:00 and 70:30 fuel proportions, respectively. However, $\mathrm{CO}$ concentration in the fuel gas decreases with time. The operating conditions and flue gas analysis results are presented in appendix (II). 


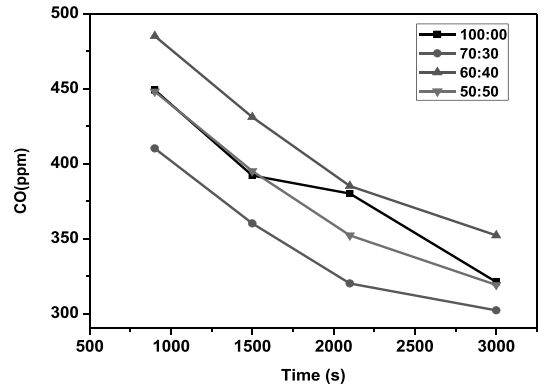

(a)

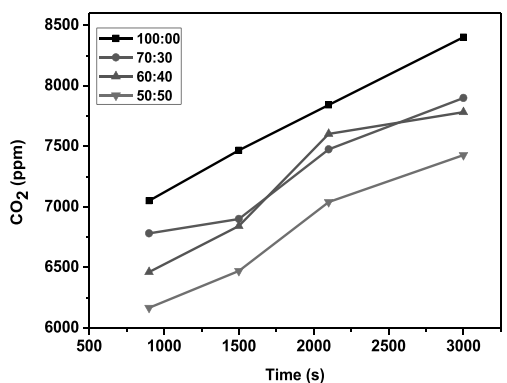

(b)

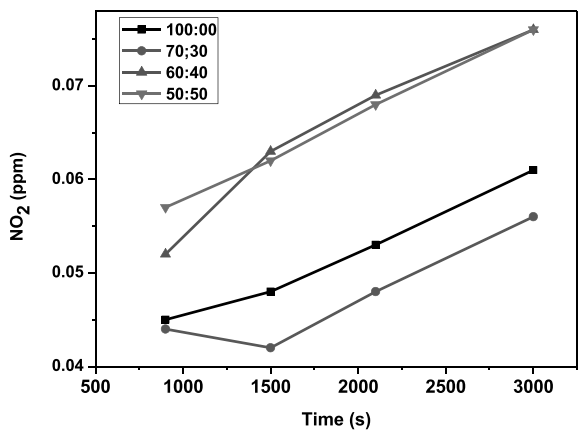

(c)

Figure 4. Effect of PKS-CH blend combustion on emissions of (a) $\mathrm{CO}$, (b) $\mathrm{CO}_{2}$, and (c) $\mathrm{NO}_{2}$.

\section{Carbon combustion efficiency}

Carbon combustion efficiency was tested for the four fuel blend proportions at different times, as shown in Figure 5. Appendix (II) shows the carbon combustion efficiency of fuel with time, along with the relevant parameters required for their prediction. For each co-combustion fuel option, combustion efficiency increases with time following the same pattern as $\mathrm{CO}_{2}$ emission. As seen in Figure 5, the combustion efficiency was characterized by its maximum of $62.11 \%$ at PKS: $\mathrm{CH}=70: 30$, which, however, showed a low $\mathrm{CO}$ emission. Thus, based on $\mathrm{CO}$ emission and ease of attaining stable combustion, a fuel blend of 70:30 PKS-CH will give better combustion in time.

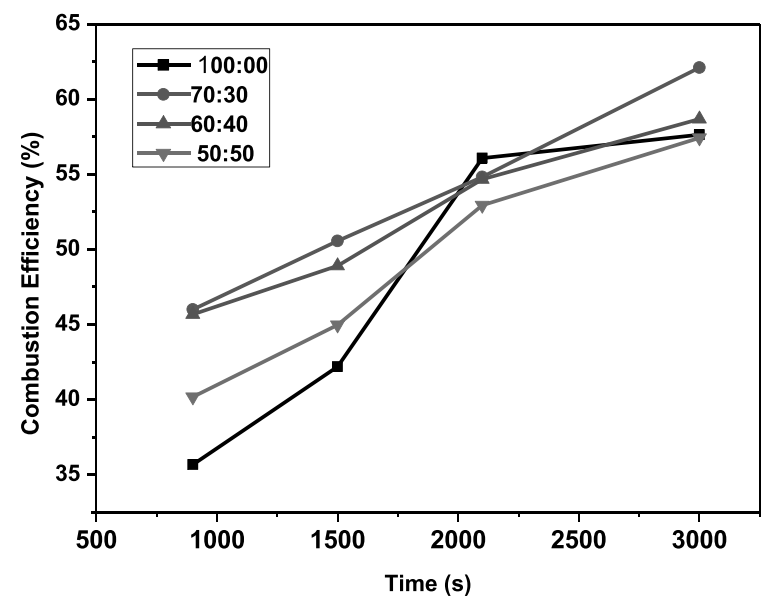

Figure 5. Combustion efficiency for PKS-CH proportions at different times. 


\section{CONCLUSIONS}

Combustion of palm kernel shell and coconut husk has been performed in a rectangular grate furnace designed as an improvement on the cylindrical grate combustor such that turbulent mixture of the fuels is achieved through a rotary mechanism. The results of a carbon combustion efficiency of $62.11 \%$ recorded at 70:30 fuel blend show that PKS could be burnt efficiently with coconut husk and that the blend proportions of these fuels have a significant effect on temperature and emission characteristics. It was found that local pyrolysis of PKS before burning aided significantly in the combustion process; however, it can be inferred that the secondary fuel (coconut husk) burns at a faster rate, which assisted in starting up the burning of PKS.

The result further indicates that palm kernel shell and coconut husk may be co-fired in a grate furnace to generate significant energy for steam power plant, while the problems associated with burning PKS alone are mediated. With a further investigation into the particle sizes of the fuel blend and an increase in excess air supply, the unburnt carbon may be significantly reduced and the combustion efficiency improved.

\section{REFERENCES}

Ahmad, W., Wan, N. \& Abdullah, N.R. 2008. Combustion Characteristics of Palm Shells and Palm Fibers Using an Inclined Grate Combustor, International Conference on Energy and Environment (ICEE), 1-8.

ASTM 3174-76. 2001. Standards method of proximate analysis of coal and coke, in gaseous fuels; coal and coke Section 5, Annual Book of ASTM Standards, 05: 299.

Basheer, A.A. 2020. Advances in materials applications in the aerospace industries. Aircraft Engineering and Aerospace Technology, 92(7): 1027-1035. https://doi.org/10.1108/AEAT-02-2020-0040

Basheer, A.A. \& Ali, I. 2019. Water photo splitting for green hydrogen energy by green nanoparticles. International Journal of Hydrogen Energy, 44(23): 11564-11573. https://doi.org/10.1016/j.ijhydene.2019.03.040

Bühler, R. 1992. Round robin tests for type testing of wood boilers. Federal Office for Energy Report, Bern.

Edmund, C.O., Christopher, M.S. \& Pascal, D.K. 2014. Characterization of palm shell for material reinforcement and water treatment. Journal of Chemical Engineering and Material Science, 5(1): 1-6.

Gaegauf, Ch. \& Salerno, B. 1991. The combustion behaviour of small wood firings. Federal Office for the energy industry, ENET, Bern

Gassman, R. 2015. Effect of dust filtration control on $\mathrm{CO}_{2}$ and $\mathrm{NH}_{3}$ concentration in a swine farrowing room. MS (Master of Science) thesis, University of Iowa.

Houshfar, E., Skreiberg, Ø., Lov_as, T., Todorovi_c, T. \& Lars, S. 2011. Effect of excess Air ratio and temperature on NOx emission from grate combustion of biomass in the staged air combustion scenario. Energy Fuels, 25:4643-4654.

Husan, Z.Z., Zainac, Z. \& Abdullah Z. 2002. Briquetting of palm fibre and shell from the processing of palm nuts to palm oil. Biomass and Bioenergy, 22: 505-509.

Kareem, B., Oladosu, K.O., Alade, A.O. \& Durowoju, M.O. 2018. Optimization of combustion characteristics of palm kernel based biofuel for grate furnace. International Journal of Energy and Environmental Engineering. https://doi.org/10.1007/ s40095-018-0277-5.

Khodaei, H., Guzzomi, F., Yeoh, G.H., Regueiro, A. \& Pati no, D. 2017. An experimental study into the effect of air staging distribution and position on emissions in a laboratory scale biomass combustor. Energy 118:1243-1255. http://dx.doi. org/10.1016/j.energy.2016.11.008

Kuijk, V. 2008. Grate furnace combustion : a model for the solid fuel layer. Eindhoven: Technische Universiteit Eindhoven https:// doi.org/10.6100/IR635154.

Najmi, W.M., Rosli, A.N. \& Izat, M.S. 2006. Combustion characteristics of palm kernel shells using an inclined grate combustor. International Conference on Energy and Environment, 2-7

Ninduangdee, P. \& Kuprianov, V.I. 2014. Combustion of palm kernel shell in a fluidized bed: optimization of biomass particle 
size and operating condition. Energy Conversion and Management. https ://doi.org/10.1016/j.encon man.2014.01.054.

Nussbaumer, T. 2003. Combustion and co-combustion of biomass: fundamentals, technologies, and primary measures for emission reduction. Energy Fuels, 17(6): 1510-1521.

Nussbaumer, Th. \& Good, J. 1998. Determination of the combustion efficiency in biomass furnaces. Proceedings 10th European Conference and Technology Exhibition Biomass for Energy, Industry and Climate Protection, Würzburg, Germany. 18081310.

Obi, F.O., Ugwuishiwu, B.O. \& Nwakaire, J.N. 2016. Agricultural waste concept, generation, utilization and management 35(4): 957-964.

Oladosu, K.O., Olamifimihan, E.O., Babatunde, K.A., Kareem, B. \& Mustapha, A.A. 2019. Investigation of stage air supply on grate combustion of palm kernel shell mixed with selected additives. Journal of Engineering and Engineering Technology, FUTAJEET 13: 47-54.

Onochie, U.P., Obanor, A.I., Aliu, S.A., Ighodaro, O.O., Entre, N.A.C. \& Nergy, F.O. 2017. Proximate and ultimate analysis of fuel pellets from oil palm residues. Nigerian Journal of Technology (NIJOTECH) 36(3): 987-990. http://dx.doi.org/10.4314/ njt.v36i3.44

Raman, P., Ram, N.K., Gupta, R., Vellaikannu U., Joseph, E. \& Sharma, M. 2011. To convert tender coconut husk into convenient form of fuel for clean combustion. New Delhi: The Energy and Resources Institute, 26. Project Report No. 2010BE11.

Salzmann, R. \& Nussbaumer, T. 2001. Fuel staging for NOx reduction in biomass combustion: Experiments and modeling. Energy Fuels, 15(3):575-582.

Sjaak, V. \& Jaap k. 2006. Handbook of biomass combustion and co-firing. ISBN-13:978-1848711043.

Skreiberg, A., Løvås, T., Houshfar, E., Skreiberg, Ø., Todorovic, D. \& Sørum, L. 2012. NOx emission reduction by staged combustion in grate combustion of biomass fuels and fuel mixtures. 98(x), 29-40. http://dx.doi.org/10.1016/j. fuel.2012.03.044

Suheri, P. \& Kuprianov, V.I. 2015. Emerging economies co-firing of oil palm empty fruit bunch and kernel shell in a fluidizedbed combustor: Optimization of operating variables. Energy Procedia, 79. Elsevier B.V. https://doi.org/10.1016/j. egypro.2015.11.593.

Thomas, R., Jabouile, F. \& Torero, J.L. 2009. Effect of excess air on grate combustion of solid wastes and on gaseous products. International Journal of Thermal Science, 165-173.

Torres-Fuchslocher, C. \& Varas-Concha, F. 2015. Design and efficiency of a small-scale woodchip furnace. Maderas: Ciencia y Tecnologia, 17(2): 355-364. https://doi.org/10.4067/S0718-221X2015005000033

Yin, C. \& Li, S. 2017. Advancing grate-firing for greater environmental impacts and efficiency for decentralized biomass/wastes combustion. Energy Procedia, 120: 373-379. https://doi.org/10.1016/j.egypro.2017.07.220.

Yin, C., Rosendahl, L.A. \& Kar, S.K. 2008. Grate-firing of biomass for heat and power production. Progress in Energy and Combustion Science, 34:725-754. https://doi.org/10.1016/j.pecs.2008.05.002. 


\section{Appendix A}

I. Temperature distribution at different positions in the furnace for different fuel proportions.

\begin{tabular}{|c|c|c|c|c|c|c|}
\hline \multirow{2}{*}{$\begin{array}{c}\text { Fuel } \\
\text { mixture }\end{array}$} & \multirow{2}{*}{$\begin{array}{l}\text { Time } \\
\text { (s) }\end{array}$} & \multicolumn{5}{|c|}{ Temperature $\left({ }^{\circ} \mathrm{C}\right)$} \\
\hline & & H1 & $\mathbf{H} 2$ & H3 & H4 & H5 \\
\hline \multicolumn{7}{|c|}{ Bed Temperature $=248.7^{\circ} \mathrm{C}$} \\
\hline \multirow{4}{*}{ 100:00 } & 900 & 299.0 & 283.6 & 263.3 & 256.2 & 288.6 \\
\hline & 1500 & 350.3 & 336.4 & 284.6 & 279.3 & 289 \\
\hline & 2100 & 390.0 & 371.5 & 314.8 & 309.6 & 319.7 \\
\hline & 3000 & 472.2 & 447.5 & 405.4 & 301.3 & 339.5 \\
\hline \multicolumn{7}{|c|}{ Bed Temperature $=311.4{ }^{\circ} \mathrm{C}$} \\
\hline \multirow{4}{*}{$70: 30$} & 900 & 512.6 & 505.6 & 456.1 & 421.4 & 486.5 \\
\hline & 1500 & 575.5 & 527.3 & 501.3 & 464.7 & 511.6 \\
\hline & 2100 & 614.7 & 558.4 & 524.2 & 491.3 & 541.5 \\
\hline & 3000 & 667.8 & 625.6 & 589.6 & 543.5 & 593.8 \\
\hline \multicolumn{7}{|c|}{ Bed Temperature $=402.5^{\circ} \mathrm{C}$} \\
\hline \multirow{4}{*}{$60: 40$} & 900 & 593.7 & 556.3 & 526.5 & 518.9 & 502.6 \\
\hline & 1500 & 626.2 & 574.1 & 541.4 & 525.6 & 514.5 \\
\hline & 2100 & 689.1 & 625.4 & 572.8 & 555.6 & 542.3 \\
\hline & 3000 & 720.9 & 658.6 & 622.8 & 607.9 & 582.1 \\
\hline \multicolumn{7}{|c|}{ Bed Temperature $=481.32^{\circ} \mathrm{C}$} \\
\hline \multirow[t]{4}{*}{$50: 50$} & 900 & 622.9 & 589.5 & 569.2 & 562.1 & 574.52 \\
\hline & 1500 & 649.1 & 632.2 & 583.4 & 578.1 & 587.2 \\
\hline & 2100 & 600.7 & 582.2 & 545.5 & 540.3 & 550.6 \\
\hline & 3000 & 555.3 & 530.3 & 488.2 & 444.1 & 422.3 \\
\hline
\end{tabular}


12 Performance evaluation of combustion of palm kernel shell and coconut husk blend in a pilot-scale grate furnace

II. Effect of fuel blend proportion on gaseous emission and combustion efficiency.

\begin{tabular}{|c|c|c|c|c|c|}
\hline \multirow[b]{2}{*}{$\begin{array}{c}\text { Fuel Proportion } \\
\text { (PKS:CH) }\end{array}$} & \multirow[b]{2}{*}{$\begin{array}{l}\text { Time } \\
\text { (s) }\end{array}$} & \multicolumn{4}{|c|}{ Parameters } \\
\hline & & $\begin{array}{c}\mathrm{CO} \\
(\mathrm{ppm})\end{array}$ & $\begin{array}{c}\mathrm{CO}_{2} \\
(\mathrm{ppm})\end{array}$ & $\begin{array}{c}\mathrm{NO}_{2} \\
(\mathbf{p p m})\end{array}$ & $\begin{array}{c}\text { Carbon Combustion } \\
\text { Efficiency (\%) }\end{array}$ \\
\hline \multirow[t]{4}{*}{ 100:00 } & 900 & 449 & 7052 & 0.045 & 35.68 \\
\hline & 1500 & 392 & 7468 & 0.048 & 42.2 \\
\hline & 2100 & 380 & 7842 & 0.053 & 56.08 \\
\hline & 3000 & 321 & 8402 & 0.061 & 57.64 \\
\hline \multirow[t]{4}{*}{$70: 30$} & 900 & 410 & 6782 & 0.044 & 46.01 \\
\hline & 1500 & 360 & 6900 & 0.042 & 50.57 \\
\hline & 2100 & 320 & 7475 & 0.048 & 54.82 \\
\hline & 3000 & 302 & 7900 & 0.056 & 62.11 \\
\hline \multirow[t]{4}{*}{$60: 40$} & 900 & 485 & 6462 & 0.052 & 45.67 \\
\hline & 1500 & 431 & 6843 & 0.063 & 48.92 \\
\hline & 2100 & 385 & 7603 & 0.069 & 54.68 \\
\hline & 3000 & 352 & 7783 & 0.076 & 58.68 \\
\hline \multirow[t]{4}{*}{$50: 50$} & 900 & 448 & 6167 & 0.057 & 40.19 \\
\hline & 1500 & 395 & 6472 & 0.062 & 44.97 \\
\hline & 2100 & 352 & 7041 & 0.068 & 52.95 \\
\hline & 3000 & 319 & 7429 & 0.076 & 57.44 \\
\hline
\end{tabular}

